GRASAS Y ACEITES 71 (4)

October-December 2020, e386

ISSN-L: 0017-3495

https://doi.org/10.3989/gya.0916192

\title{
Antioxidant, anti-inflammatory and cytotoxic activities of the unsaponifiable fraction of extra virgin olive oil
}

\author{
M.M. Elaasser ${ }^{\mathrm{a}}$, M.K.S. Morsi ${ }^{\mathrm{b}}$, S.M. Galal ${ }^{\mathrm{b},}$, M.K. Abd El-Rahman ${ }^{\mathrm{c}}$ and M.A. Katry \\ ${ }^{a}$ The Regional Center for Mycology and Biotechnology, Al-Azhar University, Cairo 11759, Egypt \\ ${ }^{b}$ Department of Food Science, Faculty of Agriculture, Cairo University, 12613 Giza, Egypt \\ ${ }^{c}$ National Nutrition Institute, Ministry of Health and Population, Cairo 11562, Egypt \\ Corresponding author: asadgalal@agr.cu.edu.eg
}

Submitted: 20 September 2019; Accepted: 02 December 2019; Published online: 14 October 2020

SUMMARY: The health benefits of olive oil are well-known. In this study, the unsaponifiable fraction of extra virgin olive oil (Unsap) was investigated for reducing power capacity, ferric reducing antioxidant power, ferrous chelating activity and nitric oxide inhibition. The present study was also designed to evaluate the in vitro cytotoxic effect of the Unsap against human carcinoma cells. The anti-inflammatory potential of Unsap has been determined via the inhibition of Human Cyclooxygenases. The results showed that Unsap is efficient for ferric reducing antioxidant power and nitric oxide inhibition. Unsap has a selective effect as anti-inflammatory agent. The results showed moderate to good in vitro antitumor activities of Unsap against human liver, lung and pancreas cancer cells with $\mathrm{IC}_{50}$ ranging from 19.6 to $30.4 \mu \mathrm{g} / \mathrm{mL}$ and good selectivity index $(\geq 2)$. In conclusion, Unsap represents a promising and safe antitumor and antioxidant material that supports the need for further investigation.

KEYWORDS: Anti-inflammatory; Antioxidant; Cytotoxicity; Olive oil; Unsaponifiable fraction

RESUMEN: Actividades antioxidantes, antiinflamatorias y citotóxicas de la fracción insaponificable de aceite de oliva virgen extra. Los beneficios para la salud del aceite de oliva son bien conocidos. En este estudio, se investigó la fracción insaponificable del aceite de oliva virgen extra (Insap) para reducir el poder antioxidante férrico, la actividad quelante ferrosa y la inhibición del óxido nítrico. El presente estudio también fue diseñado para evaluar el efecto citotóxico in vitro del Insap contra las células de carcinoma humano. La potencialidad antiinflamatoria del Insap se ha determinado mediante la inhibición de las ciclooxigenasas humanas. Los resultados mostraron que el Insap es eficiente para reducir el poder antioxidante férrico y la inhibición del óxido nítrico. El Insap tiene un efecto selectivo como agente antiinflamatorio. Los resultados mostraron actividades antitumorales in vitro del Insap de moderadas a buenas contra células de cáncer de hígado, pulmón y páncreas humano con una CI50 que varía de 19,6 a $30,4 \mu \mathrm{g} / \mathrm{ml}$ y por su buen índice de selectividad ( $\geq 2)$. En conclusión, el Insap contiene material antitumoral y antioxidante prometedor y seguro que será respaldado por investigaciones adicionales.

PALABRAS CLAVE: Aceite de oliva; Antiinflamatorio; Antioxidante; Citotoxicidad; Fracción insaponificable

ORCID ID: Elaasser MM https://orcid.org/0000-0003-0862-7628, Morsi MKS https://orcid.org/0000-0003-2061-6075, Galal SM https://orcid.org/0000-0002-1859-1641, Abd El-Rahman MK https://orcid.org/0000-0003-0474-3023, Katry MA https://orcid.org/0000-0002-2857-671X

Citation/Cómo citar este artículo: Elaasser MM, Morsi MKS, Galal SM, Abd El-Rahman MK, Katry MA. 2020. Antioxidant, anti-inflammatory and cytotoxic activities of the unsaponifiable fraction of extra virgin olive oil. Grasas Aceites 71 (4), e386. https://doi.org/10.3989/gya.0916192

Copyright: (02020 CSIC. This is an open-access article distributed under the terms of the Creative Commons Attribution 4.0 International (CC BY 4.0) License. 


\section{INTRODUCTION}

Extra virgin olive oil (EVOO) is the highest quality olive oil obtained from the olive fruit by mechanical processes. According to the Codex (2015) classification, EVOO category has free acidity, fatty acid ethyl esters, peroxide value and absorbance at $270 \mathrm{~nm}$, and not higher than $0.8 \%$, $35 \mathrm{mg} / \mathrm{kg}$ oil, 20 milliequivalents of active oxygen $/ \mathrm{kg}$ oil and 0.22 , respectively. In addition, it should be free of odor and taste defects. It consists of a major fraction of unsaturated fatty acids and the Unsap (1-2\%) composed of aliphatic and triterpenic alcohols, sterols, hydrocarbons and $\alpha$-tocopherol (Servili et al., 2014). Squalene represents the major hydrocarbon in the unsaponifiable fraction of olive oil (Cardeno et al., 2014).

The Unsap of EVOO as a natural product has anti-inflammatory and anticancer effects on human colon cancer in murine models (Cardeno et al., 2013). Escrich et al., (2011) attributed the beneficial effect of EVOO on the progression of breast cancer to its oleic acid content and its minor compounds. Dietary EVOO's Unsap prevented the damage in acute colitis and reduced pro-inflammatory protein expression to its basal levels in mice (SánchezFidalgo et al., 2013). The Unsap of virgin olive oil prevented the development and progression of neuroinflammation-related diseases in obese mice (Toscano et al., 2019). A diet rich in EVOO exerts its effect on breast cancer by reducing the level of DNA damage (Solanas et al., 2010). Several studies have confirmed that the consumption of olive oil is effective in the prevention and treatment of cardiovascular diseases, and obesity and reduces the risk of cancer, especially breast, lung and stomach cancer (Covas et al., 2009). Squalene has chemopreventive activity against colon cancer (Rao et al., 1998). Smith et al., (1998) reported that a diet that contains olive oil or squalene could effectively inhibit lung tumorigenesis and decrease lung tumor multiplicity. Warleta et al., (2010) suggested that the squalene in virgin olive oils could be partially responsible for a lower incidence of breast cancer due to its protective activity against oxidative DNA damage in normal mammary cells. Liver cancer is one of the most widespread malignant diseases (Bray et al., 2018). A polyphenolic extract of EVOO reduced cell proliferation and increased cell death of liver cancer cell lines (HepG-2, Huh7 and Hep3B) (De Stefanis et al., 2019). Olive oil phenols such as hydroxytyrosol and oleuropein are not Unsap materials (Boskou, 2015). Although, squalene and $\gamma$-Tocopherol proved to have antioxidant and anticancer activities when applied as pure substances individually (Newmark, 1997; Abraham et al., 2019), Cardeno et al., (2014) reported that there is a great lack of knowledge on the biological activity of the Unsap of EVOO. The combination of these active compounds may be useful for enhancing the effectiveness, eliminating the free radicals' destructive effects or minimizing the doses needed for inhibiting the growth of cancer cells. Therefore, the novelty of this study is the evaluation of the combined effect of the constituents present in the Unsap of EVOO on scavenging radicals, reduction in COX-2 activity and selectivity against cancer cells compared to normal cells.

\section{MATERIALS AND METHODS}

\subsection{Materials}

EVOO was obtained from the Agriculture Research Center, Giza, Egypt. Ascorbic acid, butylated hydroxytoluene (BHT), MTT and trypan blue dye were purchased from Sigma (St. Louis, MO, USA). Fetal Bovine serum, DMEM, L-glutamine, gentamycin and $0.25 \%$ Trypsin-EDTA were purchased from Lonza (Walkersville, USA). Cell lines were obtained from the VACSERA Tissue Culture Unit, the Holding Company for Biological Products and Vaccines, Egypt.

\subsection{Extraction of the unsaponifiable matter}

The saponification of EVOO $(5 \mathrm{~g})$ and extraction of the unsaponifiable matter were carried out according to the IUPAC (1992) method.

\subsection{Antioxidant assays}

\subsubsection{Ferric reducing antioxidant power (FRAP)}

The reducing power of Unsap was evaluated using the method of Oyaizu (1986). This method is based on the reduction in ferricyanide in relation to different concentrations of Unsap (from 3.9 to $2000 \mu \mathrm{g} / \mathrm{mL}$, in a geometric sequence). The absorbance was measured at $700 \mathrm{~nm}$ against a blank using a spectrophotometer (Milton Roy, Spectronic 1201). BHT was used as reference standard. The reducing capacity percentage $(\%)$ was calculated according to Canabady-Rochelle et al., (2015) as follows:

Reducing capability $(\%)=100-\left[\frac{\mathrm{A}_{0}-\mathrm{As}}{\mathrm{A}_{0}} \times 100\right]$

Where, $\mathrm{A}_{0}$ : absorbance of the control solution. As: sample absorbance.

\subsubsection{Ferrous metal chelating activity}

Different concentrations of the Unsap and reference standard (from 3.9 to $2000 \mu \mathrm{g} / \mathrm{mL}$, in a geometric sequence) were added to a solution of $\mathrm{FeCl}_{2}$ $(2 \mathrm{mM})$. The reaction was initiated by the addition 
of ferrozine $(5 \mathrm{mM})$ and the mixture was shaken vigorously and left to stand at room temperature for $10 \mathrm{~min}$. Then, the absorbance of the solution was measured at $562 \mathrm{~nm}$ using a Milton Roy (Spectronic 1201) spectrophotometer according to Gülçin et al., (2003). Decreasing absorbance in the metal chelating activity showed that metal ions were chelated before ferrozine bonding. The percentage of inhibition of ferrozine- $\mathrm{Fe}^{2+}$ complex formation was given by the formula (2):

Ferrous ion chelating activity $(\%)=\left[\frac{\mathrm{A}_{0}-\mathrm{A}_{1}}{\mathrm{~A}_{0}}\right] \times 100$

Where, $\mathrm{A}_{0}$ is the absorbance value of the control (in the presence of ferrozine and $\mathrm{Fe}^{2+}$ ions), and $\mathrm{A}_{1}$ is the absorbance value in the presence of the tested sample or standard. BHT was used as a reference standard.

\subsubsection{Nitric oxide (NO) radical scavenging activity}

The NO radical scavenging activity of Unsap was determined according to the method of Marcocci et al., (1994) by using a sodium nitroprusside (SNP). NO radical generated from SNP reacted with oxygen to produce nitrite ions, which were measured by the Greiss reagent. The concentrations of the tested Unsap ranged from 3.9 to $2000 \mu \mathrm{g} / \mathrm{mL}$ in a geometric sequence. The absorbance was measured at 546 $\mathrm{nm}$ against the corresponding blank solution (without SNP). Ascorbic acid was used as a reference standard. All the tests were performed in triplicate. The percent inhibition activity was calculated using the formula (3):

Inhibition $\%=\left[\frac{\mathrm{A}_{\text {control }}-\mathrm{A}_{\text {sample }}}{\mathrm{A}_{\text {control }}}\right] \times 100$

where, $\mathrm{A}_{\text {control }}$ is the absorbance of the control reaction at $546 \mathrm{~nm}$ and $\mathrm{A}_{\text {test }}$ represents the absorbance of a test reaction at the same wavelength. Tested material concentration providing $50 \%$ inhibition $\left(\mathrm{IC}_{50}\right)$ was calculated from the graph by plotting inhibition percentage against concentration.

\subsection{In-vitro anti-inflammatory activity (Cyclooxygenase inhibition assay)}

The cyclooxygenase inhibition assay was carried out according to Larsen et al., (1996). Different concentrations of the tested sample (from 7.8 to $1000 \mu \mathrm{g} / \mathrm{mL}$, in a geometric sequence) were preincubated with the cyclooxygenase enzymes (COX-1 and $\mathrm{COX}-2)$ at room temperature $\left(25^{\circ} \mathrm{C}\right)$ for $5 \mathrm{~min}$ in the presence of hematin. Phenol $(500 \mu \mathrm{M})$, 1-leuco-dichlorofluorescein $(20 \mu \mathrm{M})$, arachidonic acid $(50 \mu \mathrm{M})$ and hematin $(1 \mu \mathrm{M})$ in $1 \mathrm{~mL}$ of 0.1 M Tris-buffer ( $\mathrm{pH} 8$ ) were pre-mixed and added to the enzyme mixture. The absorbance was recorded within 15 seconds of the addition using a Milton Roy (Spectronic 1201) spectrophotometer at $502 \mathrm{~nm}$. A blank was made without the addition of enzymes. Celecoxib was used as a standard. The $\mathrm{IC}_{50}$ value $(\mu \mathrm{g} / \mathrm{mL})$, which is the concentration of the Unsap or standard that inhibited $50 \%$ of each cyclooxygenase, was calculated from the curve.

\subsection{In vitro anti-cancer assay}

\subsubsection{Cell line propagation}

The cytotoxic effects of Unsap were estimated in vitro against human Breast (MCF-7), Lung (A-549), Pancreas (Panc-1), Hepatocellular (HepG-2) carcinoma cells and a normal human lung cell line (WI-38). The cells were propagated in Dulbecco's modified Eagle's medium (DMEM) supplemented with $10 \%$ heat-inactivated fetal bovine serum, $1 \%$ L-glutamine, and $50 \mu \mathrm{g} / \mathrm{mL}$ gentamycin. All cells were kept at $37^{\circ} \mathrm{C}$ in a humidified atmosphere with $5 \% \mathrm{CO}_{2}$.

\subsubsection{Cytotoxicity evaluation}

The cytotoxicity assay of Mosmann (1983) was performed as follows: the cells were seeded in 96-well plates at a cell concentration of $1 \times 10^{4}$ cells per well in $100 \mu \mathrm{L}$ of growth medium. After $24 \mathrm{~h}$ of seeding, fresh medium containing different concentrations (from 3.9 to $500 \mu \mathrm{g} / \mathrm{mL}$, in a geometric sequence) of the tested sample was added. The Microtiter plates were incubated at $37{ }^{\circ} \mathrm{C}$ in a humidified incubator with $5 \% \mathrm{CO}_{2}$ for a period of $24 \mathrm{~h}$. Control cells were incubated without the tested sample. Then, the yield of viable cells was determined by a MTT colorimetric method. The absorbances of the plates were measured at a wavelength of $570 \mathrm{~nm}$ using a Microplate reader (SunRise, TECAN, Inc., USA). Treated samples were compared with the cell control in the absence of the tested compounds. Vinblastine sulfate was used as a reference anticancer drug. All experiments were carried out in triplicate. The percentage of viability was calculated as illustrated in the following formula (4)

The percentage of viability $=\left[1-\left(\frac{0 \mathrm{D}_{\mathrm{t}}}{0 \mathrm{D}_{\mathrm{c}}}\right)\right] \times 100$

Where: $\mathrm{OD}_{\mathrm{t}}$ is the mean optical density of wells treated with the tested sample and $\mathrm{OD}_{\mathrm{c}}$ is the mean optical density of the untreated cells. The relation between surviving cells and drug concentration is plotted to get the survival curve of each tumor cell 
line after treatment with the specified compound. The $50 \%$ inhibitory concentration $\left(\mathrm{IC}_{50}\right)$ or the cell cytotoxic concentration $\left(\mathrm{CC}_{50}\right)$ is the concentration required to cause toxic effects in $50 \%$ of intact cells. $\mathrm{IC}_{50}$ was estimated from the graphic plots of the dose response curve for each concentration using Graphpad Prism software (San Diego, CA. USA).

\subsection{Statistical analysis}

The results are expressed as the mean values \pm standard deviation (SD) of three experiments. The statistical analysis was carried out using Statistica software (StatSoft Inc., Tulsa, OK, USA). The Tuckey's test was used at a significance level of 5\%.

\section{RESULTS AND DISCUSSION}

Squalene represented the main component of the Unsap while $\beta$-sitosterol, and $\gamma$-tocopherol were found in minor quantities as reported previously (Cardeno et al., 2014; Galal et al., 2020).

\subsection{Antioxidant activity}

The antioxidant activity of the Unsap was analyzed by different methods (FRAP, iron chelating activity and nitric oxide radical scavenging activity) to cover various ways of antioxidant protection and the results are illustrated in Figure1.

Previous studies indicated that the antioxidant activity of some compounds is correlated with their reducing power. Figure 1a presents the reducing capacity of $\mathrm{Fe}^{3+} \rightarrow \mathrm{Fe}^{2+}$ transformation in the presence of Unsap compared to the standard. The reducing power of the investigated Unsap and the positive standard BHT was concentration dependent and reached a plateau at concentrations higher than $1000 \mu \mathrm{g} / \mathrm{mL}$. The reducing power of $1000 \mu \mathrm{g} / \mathrm{mL}$ of the Unsap was not significantly different from that of BHT $(\mathrm{p}>0.05)$ at $250 \mu \mathrm{g} / \mathrm{mL}$. The $\mathrm{IC}_{50}$ value for Unsap $(192.05 \mu \mathrm{g} / \mathrm{mL})$ was higher than that of BHT $(54.34 \mu \mathrm{g} / \mathrm{mL})$, indicating lower activity of the Unsap. Abdallah et al., (2018) found that the polyphenol methanolic extract of olive oil samples, obtained from three Tunisian cultivars, had $\mathrm{IC}_{50}$ values of FRAP ranging from 250 to $480 \mu \mathrm{g} / \mathrm{mL}$. They ascribed this activity to the hydroxytyrosol and decarboxymethyl ligstroside aglycone in the polyphenol extract.

The generation of reactive oxygen species can be avoided by the chelating of metal ions. Extracts with iron chelating activity are effective for the reduction of lipid peroxidation (Atere et al., 2018). Chelating agents disrupt the formation of the Ferrozine-Fe ${ }^{2+}$ complex and decrease the red color of the complex. The chelating effect of the Unsap on ferrous ions compared to BHT is illustrated in Figure $1 b$. The chelating efficiency of $2000 \mu \mathrm{g} / \mathrm{mL}$ of
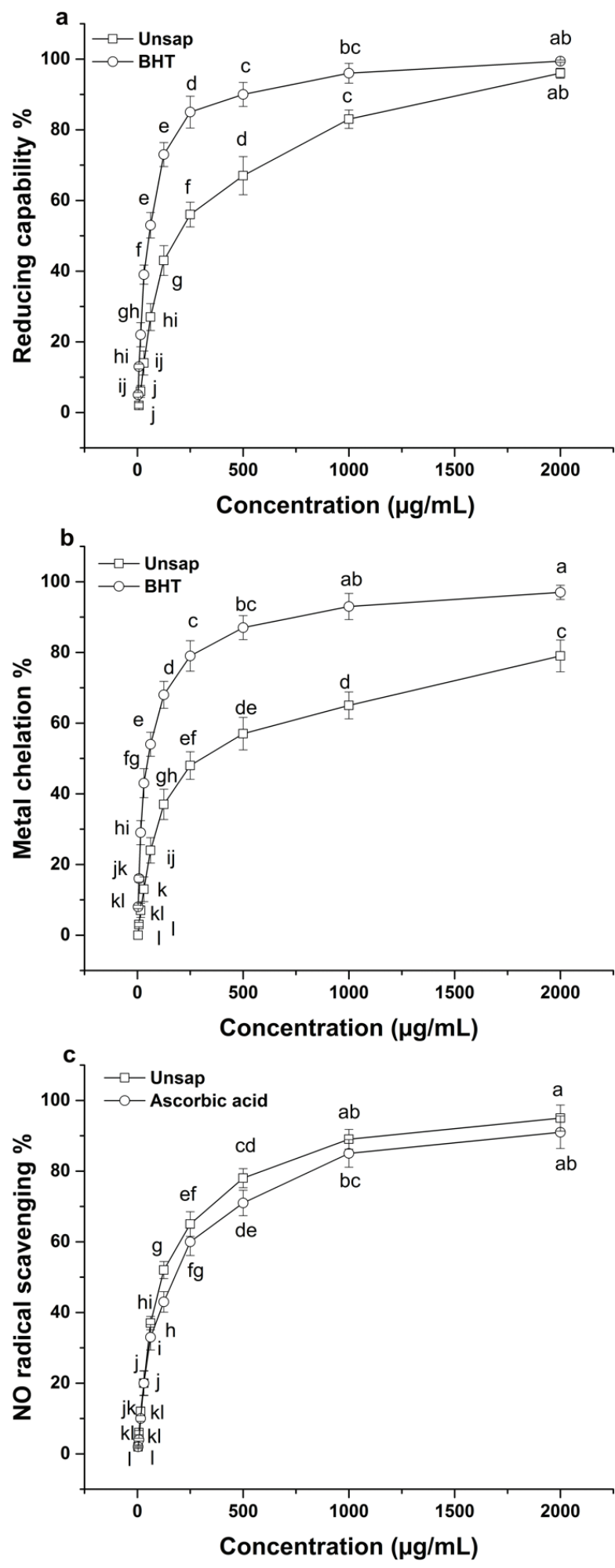

FIGURE 1. Antioxidant activity of Unsap of olive oil compared to the standard as assessed by reducing capacity compared to butylated hydroxytoluene (BHT) (a), metal chelating activity compared to BHT (b), nitric oxide (NO) radical scavenging activity compared to ascorbic acid

(c). The results are presented as average values of three replicates \pm SD. Values with different letters indicate significant differences $(\mathrm{p}<0.05)$ according to Tukey's test. 
the Unsap was not significantly different from that of BHT $(\mathrm{p}>0.05)$ at $500 \mu \mathrm{g} / \mathrm{mL}$. The $\mathrm{IC}_{50}$ value of the Unsap for chelating activity was $306.73 \mu \mathrm{g} / \mathrm{mL}$, which was higher than the positive standard BHT $\left(\mathrm{IC}_{50}=50.20 \mu \mathrm{g} / \mathrm{mL}\right)$.

Based on Figure 1c, the evaluation of nitric oxide radical (generated by sodium nitroprusside at physiological $\mathrm{pH}$ ) scavenging activity of Unsap and ascorbic acid showed a similar trend. The nitric oxide radical scavenging activity of the Unsap was not significantly different from that of the ascorbic acid $(p>0.05)$ at all the investigated concentrations. The $\mathrm{IC}_{50}$ value for Unsap $(116.7 \mu \mathrm{g} / \mathrm{mL})$ was lower than that of the ascorbic acid $(176.5 \mu \mathrm{g} / \mathrm{mL})$ indicating higher antioxidant activity. Franco et al., (2014) found that NO antiradical activity of the oils of seven Spanish olive varieties ranged from 29.8 to $40.7 \%$ at $5.6 \mathrm{mg} / \mathrm{mL}$ of olive oil methanol solution.

Based on the data obtained from this study, the tested olive oil Unsap exhibits free radical inhibitor or scavenger activity for NO radical thus acting as primary antioxidant which reacts with free radicals, and may limit free radical damage in the human body.

\subsection{Anti-inflammatory activity}

The Unsap was investigated for its efficiency to inhibit human cyclooxygenases (COX-1 and COX-2) compared with celecoxib as a standard drug. The results are shown in Figure 2. The COX enzymes were inhibited by the tested Unsap in a dose dependent manner. The investigated Unsap demonstrated a weak potency towards COX-1 (inhibition did not exceed $37.25 \%$ at $1000 \mu \mathrm{g} / \mathrm{mL}$ ), and moderate potency towards COX-2 $\left(\mathrm{IC}_{50}=412.20 \mu \mathrm{g} / \mathrm{mL}\right)$. The inhibitory effect of the Unsap at $1000 \mu \mathrm{g} / \mathrm{mL}$ on the activity of COX-2 was not significantly different from that of celecoxib ( $p>0.05$ ) at $250 \mu \mathrm{g} / \mathrm{mL}$. On the other hand, the $\mathrm{IC}_{50}$ value of the standard celecoxib on COX-1 and COX-2 was $400 \mu \mathrm{g} / \mathrm{mL}$ and $84.05 \mu \mathrm{g} / \mathrm{mL}$, respectively.

The inhibition of nitric oxide (NO) and cyclooxygenase-2 (COX-2) production is considered a promising approach for the treatment of various diseases, including inflammation and cancer as reported by Park et al., (2003). Therefore, the tested olive oil Unsap may be a useful anti-inflammatory and anticancer agent.

\subsection{Cytotoxic activity of Unsap against cancer cell lines}

The cytotoxicity of the Unsap was investigated on different cancer cell lines including MCF-7, A-549, Panc-1 and HepG-2 carcinoma cells, as shown in Figure 3. The inhibitory activity of Unsap against human lung fibroblast normal cell lines was also assayed.
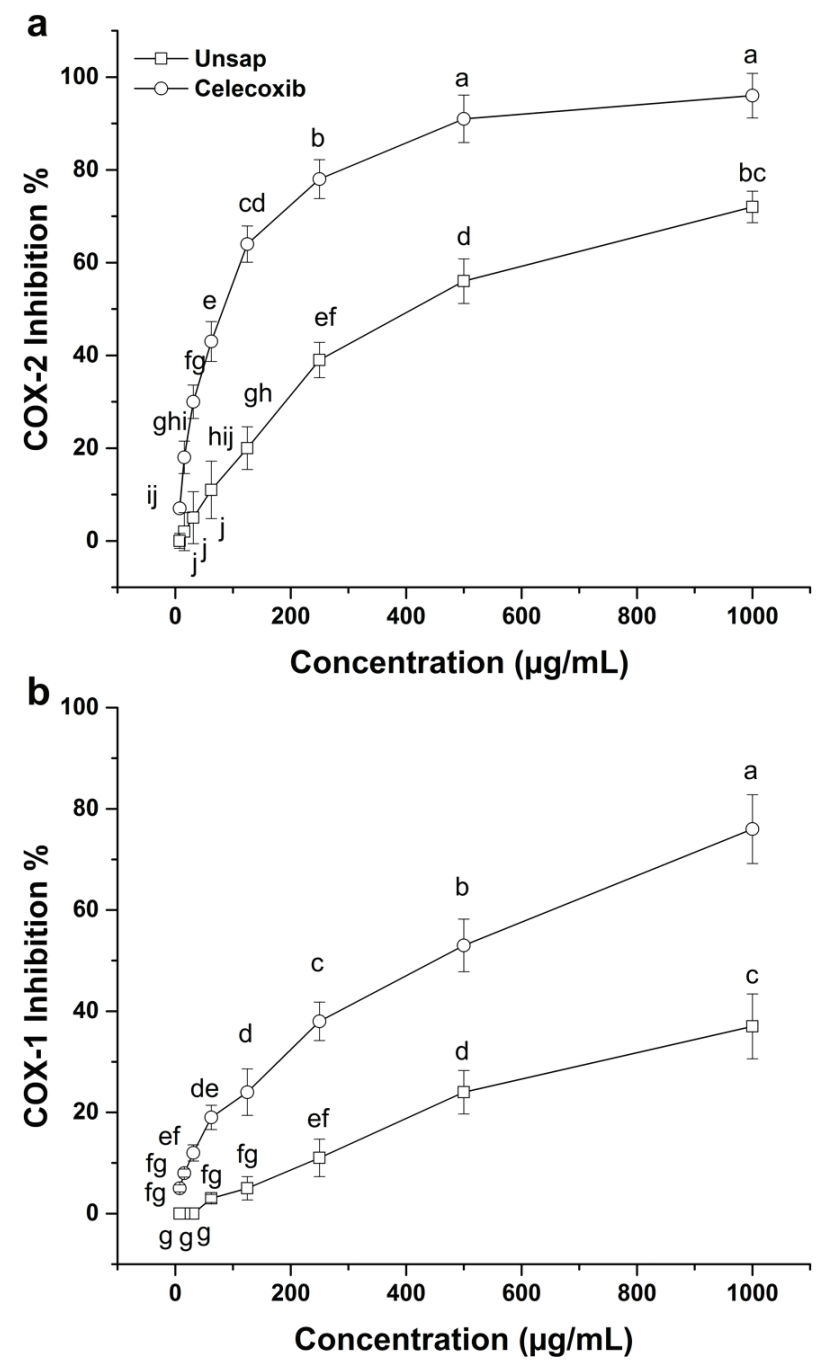

FIGURE 2. Inhibition \% of COX-1 and COX-2 by Unsap of olive oil compared with Celecoxib standard. The results are presented as average values of three replicates \pm SD Values with different letters indicate significant differences $(p<0.05)$ according to Tukey's test.

The Unsap exhibited a potential anticancer effect on the four tested cancer cell lines in a dose dependent manner. The inhibitory activities $\left(\mathrm{IC}_{50}\right.$ value) of the Unsap against MCF-7 (Figure 3a), A-549 (Figure 3b), Panc-1 (Figure 3c) and HepG-2 (Figure 3d) carcinoma cells were $45.7 \pm 2.1,30.4 \pm$ $0.7,19.6 \pm 0.8$ and $22.4 \pm 0.4 \mu \mathrm{g} / \mathrm{mL}$ instead of $5.9 \pm$ $0.9,24.6 \pm 0.7,2.89 \pm 0.12$ and $3.48 \pm 0.22 \mu \mathrm{g} / \mathrm{mL}$ for the drug vinblastine sulfate, respectively.

With regard to MCF-7, the Unsap at $125 \mu \mathrm{g} / \mathrm{mL}$ showed significantly $(\mathrm{p}<0.05)$ the same inhibition activity of $62.5 \mu \mathrm{g} / \mathrm{mL}$ of the vinblastine sulfate drug. Treating Panc-1 cancer cells with Unsap at $62.5 \mu \mathrm{g} / \mathrm{mL}$ significantly induced $(\mathrm{p}<0.05)$ the same inhibition effect as the standard drug at $15.6 \mu \mathrm{g} / \mathrm{mL}$. The inhibition effect of the Unsap at $62.5 \mu \mathrm{g} / \mathrm{mL}$ on HepG-2 cancer cells was significantly $(\mathrm{p}<0.05)$ 

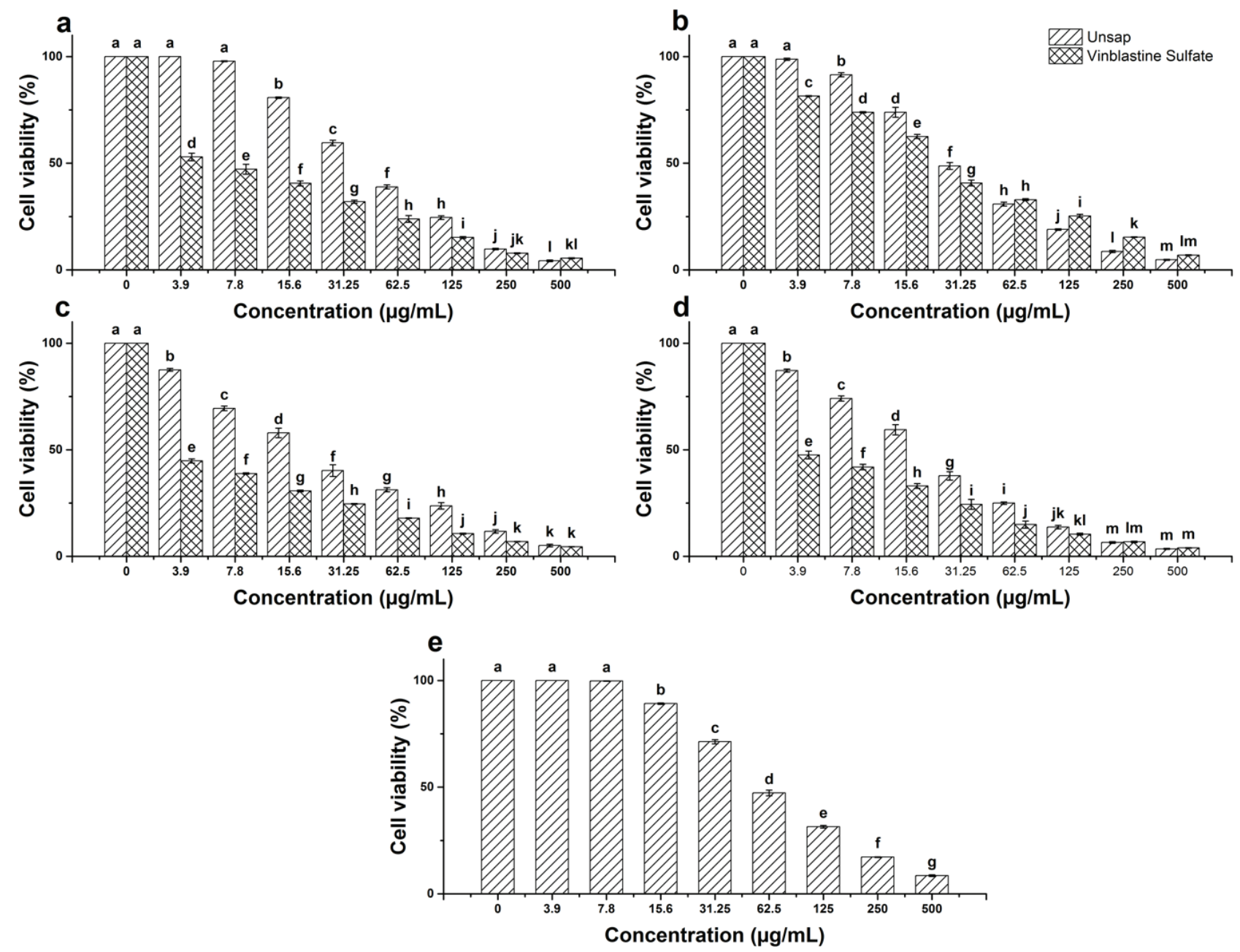

FIGURE 3. Cytotoxicity effect of Unsap and Vinblastine sulfate concentrations $(\mu \mathrm{g} / \mathrm{mL})$ against MCF-7 human breast cancer cell line (a), A-549 human lung cancer cell line (b), Panc-1 human pancreas cancer cell line (c), HepG-2 human liver cancer cell line (d), WI-38 human lung fibroblast normal cells (e). The results are represented as average values of three replicates \pm SD. Values with different letters indicate significant differences $(\mathrm{p}<0.05)$ according to Tukey's test.

similar to that of the standard drug at $31.25 \mu \mathrm{g} / \mathrm{mL}$. These results indicated that those carcinoma cells were less susceptible to the cytotoxic effect of the Unsap compared to vinblastine sulfate. It is interesting to note that Unsap and vinblastine sulfate at the concentration of $62.5 \mu \mathrm{g} / \mathrm{mL}$ have significantly $(p<0.05)$ the same inhibition effect on A-549 lung cancer cells. The results clearly showed that Unsap at concentrations higher than $62.5 \mu \mathrm{g} / \mathrm{mL}$ was significantly $(p<0.05)$ more efficient in the inhibition of A-549 cancer cells than vinblastine sulfate at the equivalent concentration.

Unsap exerts a low toxicity $\left(\mathrm{CC}_{50}=59 \pm\right.$ $3.9 \mu \mathrm{g} / \mathrm{mL}$ ) on WI-38 human lung fibroblast normal cells (Figure 3e). However, the selective index (the ratio between $\mathrm{IC}_{50}$ value for normal fibroblast cells and $\mathrm{IC}_{50}$ value for cancer cells) towards HepG-2, A-549 and Panc-1 was 2.63, 1.94 and 3.01, respectively, indicating high selective toxicity $(\geq 2)$ against those cancer cells as reported by Valderrama et al., (2016). Squalene has a chemopreventive effect against colon carcinogenesis (Rao et al., 1998). They attributed this effect to its inhibitory activity of HMG-CoA reductase and to suppressing the activation of oncogene proteins.

\section{CONCLUSIONS}

Unsap proved to have antioxidant activity and a selective cytotoxic effect against the A-549 cancer cell line. The data reveal that Unsap has anticancer activity on lung cancer cells (A-549) which is comparable to that of the drug vinblastine sulfate. These properties make Unsap a natural antioxidant and a promising anti-tumor agent for new pharmaceutical products to provide protection and treatment against the deleterious effects of free radicals. 


\section{REFERENCES}

Abdallah M, Marzocco S, Adesso S, Zarrouk M, Guerfel M. 2018. Olive oil polyphenols extracts inhibit inflammatory markers in J774A.1 murine macrophages and scavenge free radicals. Acta Histochem. 120, 1-10. https://doi. org/10.1016/j.acthis.2017.10.005

Abraham A, Kattoor AJ, Saldeen T, Mehta JL. 2019. Vitamin E and its anticancer effects. Crit. Rev. Food Sci. 59, 2831-2838. https://doi.org/10.1080/10408398.2018.1474169

Atere TG, Akinloye OA, Ugbaja RN, Ojo DA, Dealtry G. 2018. In vitro antioxidant capacity and free radical scavenging evaluation of standardized extract of Costus afer leaf. Food Science and Human Wellness 7, 266-272. https://doi. org/10.1016/j.fshw.2018.09.004

Boskou D. 2015. Olive and Olive Oil Bioactive Ingredients. AOCS Press, Urbana, IL, USA. https://doi.org/10.1016/ B978-1-63067-041-2.50007-0

Bray F, Ferlay J, Soerjomataram I, Siegel RL, Torre LA, Jemal A. 2018. Global cancer statistics 2018: GLOBOCAN estimates of incidence and mortality worldwide for 36 cancers in 185 countries. CA-Cancer J. Clin. 68, 394-424. https:// doi.org/10.3322/caac. 21492

Canabady-Rochelle LL, Harscoat-Schiavo C, Kessler V, Aymes A, Fournier F, Girardet JM. 2015. Determination of reducing power and metal chelating ability of antioxidant peptides: revisited methods. Food Chem. 15, 129-35. https:// doi.org/10.1016/j.foodchem.2015.02.147

Cardeno A, Magnusson MK, Strid H, Alarcón de La Lastra C, Sánchez-Hidalgo M, Ohman L. 2014. The unsaponifiable fraction of extra virgin olive oil promotes apoptosis and attenuates activation and homing properties of T cells from patients with inflammatory bowel disease. Food Chem. 161, 353-360. https://doi.org/10.1016/i.foodchem.2014.04.016

Cardeno A, Sánchez-Hidalgo M, Cortes-Delgado A, de la Lastra CA. 2013. Mechanisms involved in the antiproliferative and proapoptotic effects of unsaponifiable fraction of extra virgin olive oil on HT-29 cancer cells. Nutr. Cancer. 65, 908-918. https://doi.org/10.1080/01635581.20 13.806674

Codex Alimentarius Commission 2015. Codex Standard for Named Standard for Edible Fats and Oils. Codex Stan 210-1999.

Covas MI, Konstantinidou V, Fitó M. 2009. Olive oil and cardiovascular health. J. Cardiovasc. Pharmacol. 54, 477-482. https://doi.org/10.1097/FJC.0b013e3181c5e7fd

De Stefanis D, Scimè S, Accomazzo S, Catti A, Occhipinti A, Bertea CM, Costelli P. 2019. Anti-proliferative effects of an extra-virgin olive oil extract enriched in ligstroside aglycone and oleocanthal on human liver cancer cell lines. Cancers 11, 1640. https://doi.org/10.3390/cancers 11111640

Escrich E, Moral R, Solanas M. 2011. Olive oil, an essential component of the Mediterranean diet, and breast cancer. Public Health Nutr. 14, 2323-2332. https://doi.org/10.1017/ S1368980011002588

Franco MN, Galeano-Diaz T, López O, Fernández-Bolanos JG, Sánchez J, De Miguel C, Gil, MV, Martin-Vertedor D. 2014. Phenolic compounds and antioxidant capacity of virgin olive oil. Food Chem. 163, 289-298. https://doi. org/10.1016/j.foodchem.2014.04.091

Galal SM, Morsi MKS, Abd El-Rahman MK, Darwish SK, Katry MA. 2020. Hepatoprotective effect of unsaponifiable matter from olive, linseed and sesame oils against carbon tetrachloride-induced liver injury in rats. Grasas Aceites 71 (1), e345. https://doi.org/10.3989/gya.1175182

Gülçin I, Buyukokuroglu ME, Kufrevioglu OI. 2003. Metal chelating and hydrogen peroxide scavenging effects of melatonin. J. Pineal Res. 34, 278-281. https://doi.org/10.1034/ j.1600-079X.2003.00042.X
International Union of Pure and Applied Chemistry (IUPAC). 1992. Standard Methods for the Analysis of Oils, Fats and Derivatives. $7^{\text {th }}$ edn, Blackwell Scientific Publications, Oxford, England.

Larsen LN, Dahl E, Bremer J. 1996. Peroxidative oxidation of leuco-dichlorofluorescein by prostaglandin $\mathrm{H}$ synthase in prostaglandin biosynthesis from polyunsaturated fatty acids. Biochim. Biophys. Acta. 1299, 47-53. https://doi. org/10.1016/0005-2760(95)00188-3

Marcocci I, Marguire JJ, Droy-lefaiz MT, Packer L. 1994. The nitric oxide scavenging properties Ginkgo biloba extract. Biochem. Biophys. Res. Commun. 201, 748-755. https://doi. org/10.1006/bbrc.1994.1764

Mosmann T. 1983. Rapid colorimetric assay for cellular growth and survival: application to proliferation and cytotoxicity assays. J. Immunol. Methods. 65, 55-63. https://doi. org/10.1016/0022-1759(83)90303-4

Newmark HL. 1997. Squalene, olive oil, and cancer risk: A review and hypothesis. Cancer Epidemiol. Biomarkers Prev. 6, 1101-1103

Oyaizu M. 1986. Studies on products of browning reaction: Antioxidative activities of products of browning reaction prepared from glucosamine. Japn. J. Nutr. Diet. 44, 307-315. https://doi.org/10.5264/eiyogakuzashi.44.307

Park SW, Lee SG, Song SH, Heo DS, Park BJ, Lee DW, Kim KH, Sung MW. 2003. The effect of nitric oxide on cyclooxygenase-2 (COX-2) overexpression in head and neck cancer cell lines. Int. J. Cancer. 107, 729-738. https://doi. org/10.1002/ijc.11498

Rao CV, Newmark HL, Reddy BS. 1998. Chemopreventive effect of squalene on colon cancer. Carcinogenesis 19, 287-290. https://doi.org/10.1093/carcin/19.2.287

Sánchez-Fidalgo S, Cárdeno A Sánchez-Hidalgo M, AparicioSoto M, Villegas I, Rosillo MA, de la Lastra CA. 2013. Dietary unsaponifiable fraction from extra virgin olive oil supplementation attenuates acute ulcerative colitis in mice. Eur. J. Pharm. Sci. 48, 572-581. https://doi.org/10.1016/j. ejps.2012.12.004

Servili M, Sordini B, Esposto S, Urbani S, Veneziani G, Di Maio I, Selvaggini R, Taticchi, A. 2014. Biological activities of phenolic compounds of extra virgin olive oil. Antioxidants 3, 1-23. https://doi.org/10.3390/antiox3010001

Smith TJ, Yang GY, Seril DN, Liao J, Kim S. 1998. Inhibition of 4-(methylnitrosamino)-1-(3-pyridyl)-1-butanone induced lung tumorigenesis by dietary olive oil and squalene. Carcinogenesis 19, 703-706. https://doi.org/10.1093/ carcin/19.4.703

Solanas M, Grau L, Moral R, Vela E, Escrich R, Escrich E. 2010. Dietary olive oil and corn oil differentially affect experimental breast cancer through distinct modulation of the p21Ras signaling and the proliferation-apoptosis balance. Carcinogenesis 31, 871-879. https://doi.org/10.1093/ carcin/bgp243

Toscano R, Millán-Linares M C, Naranjo M C, Lemus-Conejo A, Claro C, Montserrat-de la Paz S. 2019. Unsaponifiable and phenolic fractions from virgin olive oil prevent neuroinflammation skewing microglia polarization toward M2 phenotype. J. Funct. Foods 62, 103543. https://doi. org/10.1016/j.jff.2019.103543

Valderrama JA, Delgado V, Sepúlveda S, Benites J, Theoduloz C, Buc Calderon P, Muccioli GG. 2016. Synthesis and cytotoxic activity on human cancer cells of novel isoquinoline quinone-amino acid derivatives. Molecules 21, 1-14. https://doi.org/10.3390/molecules21091199

Warleta F, Campos M, Allouche Y, Sánchez-Quesada C, RuizMora J, Beltrán G, Gaforio JJ. 2010. Squalene protects against oxidative DNA damage in MCF10A human mammary epithelial cells but not in MCF7 and MDA-MB-231 human breast cancer cells. Food Chem. Toxicol. 48, 1092-1100. https://doi.org/10.1016/j.fct.2010.01.031 